\title{
DIFFERENCE IN MARKERS OF MICROBIAL TRANSLOCATION AND CELL APOPTOSIS IN HIV MONOINFECTED AND HIV/HCV COINFECTED PATIENTS
}

\author{
Monta Madelāne ${ }^{1,2, \#}$, Angelika Krūmiṇa ${ }^{1}$, Raimonds Sīmanis ${ }^{1}$, G̦irts Šḳenders ${ }^{2,3}$, \\ Andrejs Ivanovs ${ }^{1}$, Gunta Stūre ${ }^{1,2}$, and Ludmila Vīksna ${ }^{1,2}$ \\ ${ }^{1}$ Department of Infectology and Dermatology, Rīga Stradinš University, 3 Linezera Str., Rĩga, LV-1006, LATVIA \\ ${ }^{2}$ Rīga East University Hospital, 2 Hipokrāta Str., Rīga, LV-1038, LATVIA \\ ${ }^{3}$ Institute of Clinical and Preventive Medicine, University of Latvia, 19 Raina blvd., Rīga, LV-1586, LATVIA \\ \# Corresponding author, monta.madelane@rsu.lv
}

Contributed by Ludmila Vỉksna

\begin{abstract}
Immune activation in human immunodeficiency virus (HIV) infection is driven by microbial translocation and in HIV patients is one of the contributors to faster progression of liver disease along with increased cell apoptosis. The aim of the study was to compare microbial translocation and apoptosis markers in HIV monoinfected and HIV/hepatitis C virus (HCV) coinfected patients, depending on HIV immune status and antiretroviral treatment (ART). We analysed data for 78 HIV monoinfected and $105 \mathrm{HIV/HCV}$ coinfected patients from the Riga East University Hospital. Lipopolysaccharide (LPS), endotoxin core antibodies (EndoCAb), cytokeratin 18 (CK18) and cytochrome c (Cyt-c) levels were measured. No significant difference in LPS, EndoCAb, Cyt-c levels between HIV and HIV/HCV patients was found. The CK18 level was higher in the HIV/HCV group. Correlation between CD4+ cell count and EndoCAb antibodies was found in HCV positive patients. There was a significant effect of ART on markers for EndoCAb IgA and EndoCAb IgM antibodies in the HIV monoinfected group. Correlation between CD4+ cell count and EndoCAb antibodies and LPS was found in HIV/HCV patients on ART. Coinfection with HCV can lead to more pronounced response in EndoCAb antibody production and higher levels of cell apoptosis markers, despite similar LPS levels. ART has a positive effect on immune activation.
\end{abstract}

Key words: microbial translocation, lipopolysaccharide, apoptosis.

\section{INTRODUCTION}

Immune activation is a strong predictor of disease progression in human immunodeficiency virus (HIV) infection (Sandler et al., 2011). One of the drivers of immune activation in HIV infection is microbial translocation by passing of microbial components like lipopolysaccharide (LPS) and $16 \mathrm{~S}$ ribosomal DNA (16S rDNA) into peripheral circulation, which occurs due to structural damage and loss of integrity of the gastrointestinal tract in chronic HIV infection in the absence of overt bacteraemia (Sandler et al., 2011; Marchetti et al., 2008, 2011; Sandler and Douek, 2012; Vassallo et al., 2012) and independently of opportunistic infections (Epple et al., 2009).

The presence of intestinal bacteria in the blood stream induces production of different host response molecules, like antibodies against LPS (or endotoxin) core antigen (Endo$\mathrm{CAb}$ ), lipopolysaccharide binding protein (LPB), and soluble CD14 (sCD14) (Marks et al., 2012; Epeldegui et al., 2018). However, sustained increase of LPS in chronic HIV infection can lead to enhanced consumption and therefore lower levels of EndoCAb antibodies, especially IgM antibodies, compared with the respective levels in healthy controls (Marchetti et al., 2013; Dinh et al., 2015; Epeldegui et al., 2018).

Microbial translocation has also been reported in other diseases and states, like, inflammatory bowel disease (IBD), cardiovascular diseases and neurocognitive function decline (Brenchley et al., 2006; Balagopal et al., 2008; Marchetti et al., 2013). The role of microbial translocation has been extensively studied in various liver diseases, as liver plays a 
crucial role in the removal of LPS from circulation (Marchetti et al., 2013).

Hepatitis C virus (HCV) infection is commonly found in HIV infected patients, especially in those with history of intravenous drug abuse. It is known that HIV coinfection with $\mathrm{HCV}$ accelerates progression of liver disease, but the mechanisms involved in this process are not fully understood. Many authors have reported increased levels of microbial translocation products in patients with dual HIV/HCV infection (Balagopal et al., 2008; French et al., 2013; Marquez et al., 2015). This suggests that in patients affected by both HIV and HCV viruses, levels of microbial translocation markers like LPS can be raised, as in monoinfected patients, and might promote liver fibrosis by directly influencing Kupfer cells or indirectly by inducing apoptotic cell death due to enhanced immune activation (Novati et al., 2015). Moreover, recent data shows a positive effect of $\mathrm{HCV}$ treatment in reduction of the level of microbial translocation and consequent immune activation in HIV/ HCV coinfected patients (Lopez-Cortes et al., 2018).

Microbial translocation can be measured by directly assessing bacterial by-products, like LPS, bacterial DNA or RNA fragments, or indirectly by soluble CD14, LPB and Endo$\mathrm{CAb}$ antibodies (Marchetti et al., 2011; Abad-Fernandez et al., 2013; Marchetti et al., 2013).

HIV may alter liver function by different means, both direct and indirect. The presence of HIV virus in Kupffer cells consequently leads to productive infection (Crane et al., 2012). Cell apoptosis, a highly regulated process, occurs during many physiological as well as pathological processes (Parfieniuk-Kowerda et al., 2013) and can be triggered by the extrinsic (death receptor) or the intrinsic (mitochondrial) death pathways. In HIV infection exaggerated cell apoptosis has been reported by many authors (Hansjee et al., 2004; Vassena et al., 2007; Mhawej et al., 2009), some of them suggesting that higher levels of apoptosis are associated with worse outcomes due to slower recovery of CD4+ T lymphocyte number (de Oliveira Pinto et al., 2002; Roger et al., 2002). One of the reasons for the accelerated evolution of $\mathrm{HCV}$ in $\mathrm{HIV} / \mathrm{HCV}$ coinfected patients is explained by enhanced hepatocyte apoptosis (Macias et al., 2005).

During apoptosis several regulatory substances are released into the bloodstream, including cell mitochondrial protein cytochrome-c (Cyt-c) (Parfieniuk-Kowerda et al., 2013) and Cytokeratin 18 neoepitope. Cytokeratin 18 (CK18) filaments are major components of the cytoskeleton of hepatocytes, but also occur in epithelial and parenchymal cells in smaller amounts. An increase of amount of CK18 fragments in peripheral blood due to apoptosis has been reported in different liver diseases, including HCV (Kronenberger et al., 2005; Seidel et al., 2005; Parfieniuk-Kowerda et al., 2013).

During the last decades, HIV infection has become a manageable disease due to effective antiretroviral treatment (ART), though chronic immune activation can persist and stimulate HIV progression despite viral suppression below detectable limits (Hatano, 2013; Dinh et al., 2015). Antiretroviral treatment can successfully reduce the levels of LPS and bacterial DNA in HIV-infected patients, which usually occurs after a prolonged period of ART, although the leves do not or rarely reach those of uninfected individuals (Brenchley et al., 2006; Marchetti et al., 2008; Jiang et al., 2009).

Both processes, microbial translocation and apoptosis, are studied as drivers of HIV and HCV disease progression and might be mutually related.

We aimed to evaluate the levels of LPS, EndoCAb IgA, IgM and IgG antibodies, CK18 neoepitope and Cyt-c levels in HIV monoinfected and coinfected with $\mathrm{HCV}$ patients, to detect potential interaction between those markers, in relation to HIV immune status and ART.

\section{MATERIALS AND METHODS}

The study was performed at the Rīga East University Hospital. A total of 183 chronically HIV1 infected patients (males 116, females 67) for whom frozen plasma and serum samples were available for additional testing were retrospectively included in the study. Patients with known active HIV opportunistic infection, viral hepatitis B infection, alcoholic liver disease, reported liver cirrhosis or neoplasia of any origin were excluded from the study. Patients were divided into two study arms depending on existing $(n=78)$ or no $(n=105)$ coinfection with chronic HCV.

HIV immune status was based on CD4+ T cell count at the study time. For subgroup analysis patients were grouped according to CD4+ $\mathrm{T}$ cell count in microlitre in three groups $(<200,200-500,>500)$.

The HIV diagnosis was established on positive HIV1/2 antibody testing. HIV1 RNA levels in plasma were measured by quantitative polymerase chain reaction assay using the COBAS AmpliPrep/ COBAS TaqMan HIV-1 Test 2.0 (Roche Molecular Systems, USA) with the lowest limit of sensitivity 20 copies in $1 \mathrm{ml}$.

HCV status was based on a positive anti HCV test (ELISA Monolisa HCV Ag-Ab ULTRA, Bio-Rad, France or ELISA Ortho HCV 3.0, Ortho-Clinical Diagnostics Inc., USA) and confirmed by HCV RNA detection with polymerase chain reaction (COBAS AmpliPrep/ COBAS TaqMan HCV test, Roche, USA) or HCV Core Ag (ELISA Architect system HCV Ag, Abbott, USA) presence in patient plasma.

The CD4+ $\mathrm{T}$ cell count was determined in fresh whole blood using a Partec IVD Flow Cytometer (Partec, Germany) according to the manufacturer's instructions.

All of the following markers were assayed on frozen samples following the manufacturer's recommendations and protocols. 
Endotoxin core immunoglobulin antibody (EndoCAb) ( $\operatorname{IgA}$, IgM, IgG) levels were determined in patient sera using enzyme- linked immunosorbent assay kits from Hycult (Uden, The Netherlands). The lowest limit of sensitivity for $\operatorname{IgA}$ antibodies was $0.16 \mathrm{U} / \mathrm{ml}$, with measurement range $0.16-10$ $\mathrm{U} / \mathrm{ml}$; for IgM antibodies $0.05 \mathrm{U} / \mathrm{ml}$, measurement range 0.05-3.5 U/ml; for IgG antibodies $0.13 \mathrm{U} / \mathrm{ml}$, measurement range $0.13-8 \mathrm{U} / \mathrm{ml}$. EndoCAb antibody levels were measured in 81 patients ( 33 with $\mathrm{HCV}$ and 48 without $\mathrm{HCV}$ ).

Lipopolysaccharide levels (LPS) were estimated in patient plasma using Limulus amebocyte lysate assay from Hycult (Uden, Netherlands). The lowest limit of sensitivity for lipopolysaccharide detection was $0.04 \mathrm{EU} / \mathrm{ml}$, with measurement range $0.04-10.0 \mathrm{EU} / \mathrm{ml}$.

Cytokeratin 18 neoepitope levels were determined according to manufacturer's recommendations using a M30 Apoptosense ELISA kit Peviva (VLV bio, Sweden). The minimum detectable concentration defined by the manufacturer was $20 \mathrm{U} / 1$, with detection range 0-1000 U/l.

Cytochrome $\mathrm{C}$ levels were determined using a Human cytochrome C ELISA test (Bender MedSystems, Austria) with lower sensitivity level less than $0.08 \mathrm{ng} / \mathrm{ml}$.

Statistical analysis. The Kolmogorov-Smirnov test was used to assess normality of continuous data. Descriptive statistics of LPS was reported as mean $(\mathrm{M}) \pm$ Standard Deviation (SD), for the rest of biomarkers (EndoCAb antibodies, CK18, Cyt-c) as median (Me) and interquartile range (IQR). Differences between groups were analysed using nonparametric and parametric methods. Quantitative variables were compared between two groups using the Mann-Whitney test and between three and more groups using the Kruskal-Wallis test. Qualitative variables were compared using the Chi-Square Test. For associations of variables the Spearman's correlation test was used. Statistical differences and associations were considered significant when $p<0.05$. For statistical analysis IBM SPSS 23.0 was used.

The study was conducted in accordance to the Declaration of Helsinki ethical standards. The Rịga East University Hospital Support Foundation Ethics Committee provided approval for the study.

\section{RESULTS}

The patient characteristics including age, sex, history of intravenous drug usage (IVDU), received antiretroviral treatment and CD4+ T cell count are summarised in Table 1. HIV antiretroviral treatment regimens did not differ between study arms and were based on two nucleosides and either non-nucleoside or protease inhibitor combination.

None of the parameters of microbial translocation significantly differed between $\mathrm{HCV}$ positive and $\mathrm{HCV}$ negative groups, but the HCV group had a lower plasma level of LPS $(p=0.487)$ and higher levels of all EndoCAb antibodies tested (Table 2). Regarding apoptosis markers, the CK18
Table 1

COMPARISON OF PATIENT CHARACTERISTICS BETWEEN HCV POSITIVE AND HCV NEGATIVE STUDY ARMS

\begin{tabular}{|c|c|c|c|}
\hline Variable & $\begin{array}{c}\text { HCV positive } \\
(\mathrm{n}=78)\end{array}$ & $\begin{array}{c}\text { HCV negative } \\
(\mathrm{n}=105)\end{array}$ & $p$ value \\
\hline Sex, $n$ & & & 0.574 \\
\hline Male & 47 & 69 & \\
\hline Female & 31 & 36 & \\
\hline Age, median years (IQR) & $36(31-44)$ & $38(30-44)$ & 0.630 \\
\hline Intravenous drug usage, $\mathrm{n}$ & 56 & 11 & \\
\hline $\begin{array}{l}\text { HIV antiretroviral treatment } \\
(\text { ART }), n\end{array}$ & & & 0.721 \\
\hline ART & 34 & 50 & \\
\hline no treatment & 44 & 55 & \\
\hline $\mathrm{CD} 4+$ cell count $($ cells $/ \mu \mathrm{l}), \mathrm{n}$ & & & 0.069 \\
\hline$>500$ & 14 & 27 & \\
\hline $200-499$ & 39 & 56 & \\
\hline$<200$ & 25 & 22 & \\
\hline $\begin{array}{l}\text { CD4+ cell count }(\text { cells } / \mu \mathrm{l}), \text { me- } \\
\text { dian (IQR) }\end{array}$ & $310(136-432)$ & $336(247-500)$ & $<0.080$ \\
\hline $\begin{array}{l}\text { HIV RNA copies/ml, median } \\
\text { (IQR) }\end{array}$ & $\begin{array}{c}761(<20- \\
33700)\end{array}$ & $\begin{array}{c}186(<20- \\
24500)\end{array}$ & 0.243 \\
\hline
\end{tabular}

$\overline{\mathrm{HCV} \text {, hepatitis } \mathrm{C}}$ virus; HIV, human immunodeficiency virus; IQR, interquartile range

Table 2

SERUM LEVELS OF LPS, ENDOCAB ANTIBODIES, CK18 AND CYT-C IN HIV MONOINFECTED AND COINFECTED WITH HCV INDIVIDUALS

\begin{tabular}{lccc}
\hline \multicolumn{1}{c|}{ Variable } & $\begin{array}{c}\text { HCV positive } \\
(\mathrm{n}=78)\end{array}$ & $\begin{array}{c}\text { HCV negative } \\
(\mathrm{n}=105)\end{array}$ & $p$ value \\
\hline $\mathrm{LPS}, \mathrm{EU} / \mathrm{ml}$ & $9.81 \pm 3.81$ & $10.28 \pm 4.99$ & 0.487 \\
EndoCAb IgA, & 35.09 & 31.69 & 0.085 \\
$\mathrm{U} / \mathrm{ml}$ & $(23.28-117.34)$ & $(17.50-64.84)$ & \\
EndoCAb IgM, & 24.10 & 16.03 & 0.312 \\
$\mathrm{U} / \mathrm{ml}$ & $(13.70-58.16)$ & $(14.14-20.83)$ & \\
EndoCAb IgG, & 114.05 & 93.77 & 0.709 \\
$\mathrm{U} / \mathrm{ml}$ & $(51.77-305.21)$ & $(69.72-224.70)$ & \\
$\mathrm{CK} 18, \mathrm{U} / 1$ & 198.30 & 179.30 & 0.001 \\
& $(163.0-258.83$ & $(157.30-221.20)$ & \\
Cyt-c, ng/ml & $0.30(0.24-0.73)$ & $0.27(0.24-0.35)$ & 0.542 \\
\hline
\end{tabular}

For abbreviations see Table 1. LPS, lipopolysaccharide. EndoCAb, endotoxin core antibodies; CK18, cytokeratin 18; Cyt-c, cytochrome c

level was significantly higher in the HCV group, $p<0.001$. Cyt-c levels were similar in the two groups $(p=0.542)$.

To test for differences depending on patient immune status, we made a subgroup analysis based on CD4+ T cell count within and between each of the study arms. No difference in LPS levels was found between subgroups based on CD4+ T cell count, both within each of the study arms - HCV positive $(p=0.487)$, HCV negative $(p=0.700)$, and for each CD4+ T cell-based subgroup between HCV positive and HCV negative study arms (Table 3 ). No significant difference was found in EndoCAb level in CD4+ T cell based subgroup analysis between study arms (Table 4). Within of 
Table 3

LPS LEVELS (EU/ML) IN HIV MONOINFECTED AND COINFECTED WITH HCV PATIENTS IN SUBGROUP ANALYSIS BASED ON CD4+ T CELL COUNT

\begin{tabular}{l|c|c|c}
\hline $\begin{array}{c}\text { CD4+ T cell } \\
\text { count/ } \mu \mathrm{l}\end{array}$ & $\begin{array}{c}\text { HCV positive } \\
(\mathrm{n}=73)\end{array}$ & $\begin{array}{c}\text { HCV negative } \\
(\mathrm{n}=98)\end{array}$ & $p$ value \\
\hline$<200$ & $9.33 \pm 4.34$ & $10.90 \pm 7.47$ & 0.410 \\
$200-500$ & $10.32 \pm 3.69$ & $10.33 \pm 4.06$ & 0.990 \\
$>500$ & $9.23 \pm 3.03$ & $9.65 \pm 4.27$ & 0.720
\end{tabular}

For abbreviations see Table 1

Table 4

ENDOCAB LEVELS (U/ML) IN HIV MONOINFECTED AND COINFECTED WITH HCV PATIENTS IN SUBGROUPS BASED ON CD4+ T CELL COUNT

\begin{tabular}{|c|c|c|c|}
\hline $\begin{array}{c}\text { CD4+ T cell } \\
\text { count } / \mu \mathrm{l}\end{array}$ & $\begin{array}{l}\text { HCV positive } \\
\quad(\mathrm{n}=33)\end{array}$ & $\begin{array}{l}\text { HCV negative } \\
\quad(\mathrm{n}=48)\end{array}$ & $p$ value \\
\hline \multicolumn{4}{|c|}{ EndoCAb IgA, U/ml } \\
\hline$<200$ & $133.11(49.73-149.58)$ & $34.77(19.58-56.22)$ & 0.115 \\
\hline $200-500$ & $35.39(18.75-84.39)$ & $22.67(15.57-41.17)$ & 0.074 \\
\hline$>500$ & $25.48(20.21-30.37)$ & $37.70(21.08-122.40)$ & 0.291 \\
\hline \multicolumn{4}{|c|}{ EndoCAb IgM, U/ml } \\
\hline$<200$ & $47.67(11.73-83.94)$ & $18.76(16.93-68.25)$ & 0.528 \\
\hline $200-500$ & $18.01(12.58-40.84)$ & $15.90(13.05-19.85)$ & 0.530 \\
\hline$>500$ & $27.96(17.96-58.53)$ & $16.50(13.30-26.27)$ & 0.083 \\
\hline \multicolumn{4}{|c|}{ EndoCAb IgG, U/ml } \\
\hline$<200$ & $388.39(229.46-396.73)$ & $295.24(139.91-426.44)$ & 0.834 \\
\hline $200-500$ & $95.50(51.90-256.85)$ & $78.02(63.06-148.48)$ & 0.558 \\
\hline$>500$ & $65.39(49.65-132.59)$ & $94.98(76.29-250.29)$ & 0.250 \\
\hline
\end{tabular}

For abbrev. see Table 2.

each of the study arms, significantly higher levels of Endo$\mathrm{CAb}$ IgG antibodies were observed in patients having low $\mathrm{CD} 4+\mathrm{T}$ cell count, both in the HCV positive arm ( $p=$ $0.029)$ (Fig. 1) and HCV negative arm ( $p=0.025)$ (Fig. 2). For HCV positive patients the main difference occurred between CD4+ T cell count $>500 / \mu \mathrm{l}$ and $<200 / \mu \mathrm{l}$ groups, $\mathrm{p}=$ 0.04. In HCV negative patients the distribution of IgG antibodies across CD4+ $\mathrm{T}$ cell based subgroups differed, with the largest difference between $200-500 / \mu l$ and $<200 / \mu \mathrm{l}$ groups, $p=0.021$. A similar relationship was seen for EndoCAb IgA antibodies, but statistical significance was attained only for patients coinfected with $\mathrm{HCV}(p=0.029)$ and not for the HCV negative group $(p=0.156)$. The main difference was between groups with CD4+ T cells $>500 / \mu \mathrm{l}$ and $<200$ cells $/ \mu$ l, $p=0.027$, whereas differences between other groups were not statistically significant.

A similar analysis between study arms was performed for apoptosis markers; statistical significance between study arms was reached for CK18 levels in patients with CD4+ T cell count more than 200 cells/ $\mu$, but not for patients with CD4+ T cell count less than 200 cells/ $\mu$ (Table 5). Within study arms, no differences between CD4+ T cell based subgroups were found for CK18 levels in HCV positive patients $(p=0.164)$, nor in HCV negative patients $(p=0.862)$.

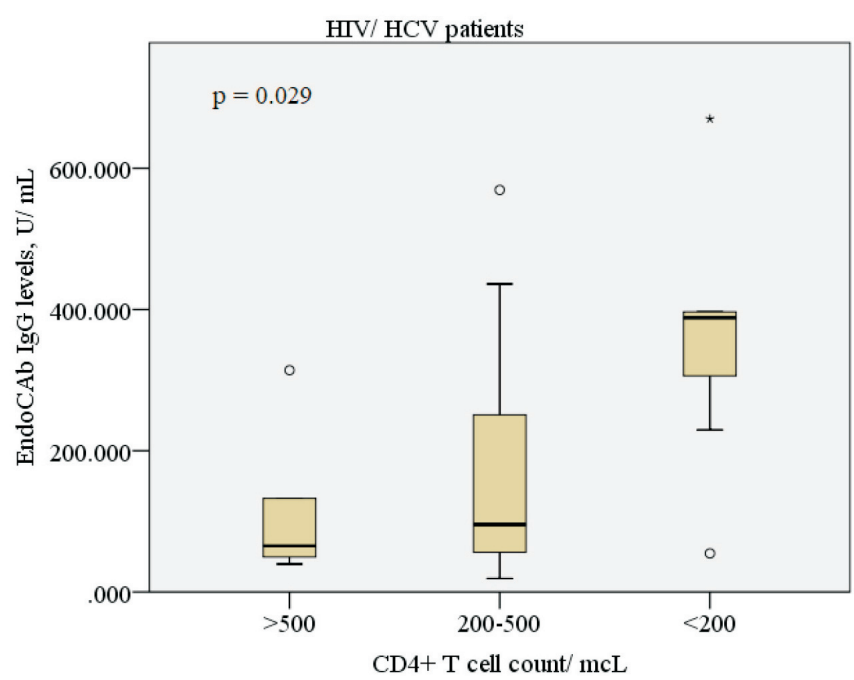

Fig. 1. EndoCAb IgG levels (U/ml) in hepatitis $\mathrm{C}$ virus (HCV) positive patients according to CD4+ $\mathrm{T}$ cell count

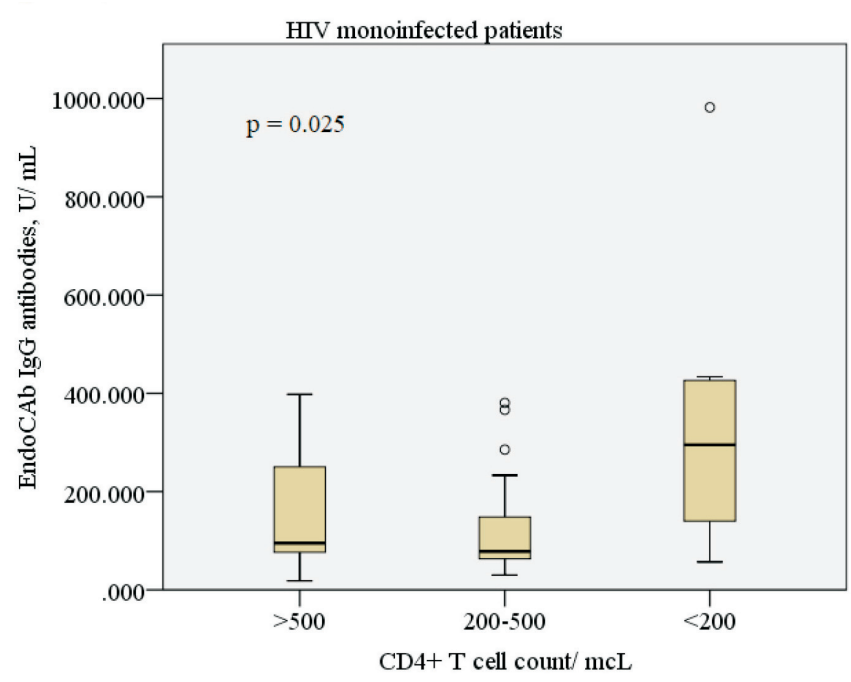

Fig. 2. EndoCAb IgG levels $(\mathrm{U} / \mathrm{ml})$ in $\mathrm{HCV}$ negative patients according to CD4+ T cell count

Table 5

CK18 LEVELS (U/L) IN HIV MONOINFECTED AND COINFECTED WITH HCV PATIENTS IN SUBGROUP ANALYSIS BASED ON CD4+ T CELL COUNT

\begin{tabular}{c|c|c|c}
\hline $\begin{array}{c}\text { CD4+ T cell } \\
\text { count/ } \mu \mathrm{l}\end{array}$ & $\begin{array}{c}\text { HCV positive } \\
(\mathrm{n}=78)\end{array}$ & $\begin{array}{c}\text { HCV negative } \\
(\mathrm{n}=105)\end{array}$ & $p$ value \\
\hline 200 & $177.50(146.50-226.65)$ & $175.75(136.60-192.83)$ & 0.267 \\
$200-500$ & $204.00(162.40-263.40)$ & $161.70(136.70-187.80)$ & 0.001 \\
500 & $204.90(164.80-388.20)$ & $162.40(140.60-191.10)$ & 0.032
\end{tabular}

For abbrev. see Table 1.

Cyt-c levels were similar in patients with different CD4+ T cell counts.

To test for possible associations between microbial translocation and HIV disease activity, we looked for associations between LPS, CD4+ T cell count, HIV RNA and EndoCAb antibodies. In the $\mathrm{HCV}$ positive patient group, CD4+ T cell 
count was negatively correlated with EndoCAb $\operatorname{IgA}\left(\mathrm{r}_{\mathrm{s}}=\right.$ $-0.339, p=0.05)$ and EndoCAb $\operatorname{IgG}\left(\mathrm{r}_{\mathrm{s}}=-0.497, p=\right.$ $0.004)$, but significant correlation was not found for Endo$\mathrm{CAb} \operatorname{IgM}\left(\mathrm{r}_{\mathrm{s}}=0.275, p=0.127\right)$. Also, significant correlations was not found between those parameters in HIV monoinfected patients.

To test for possible influence of ART on microbial translocation and cell apoptosis, we analysed marker levels in each of the study arms according to ART received. The only parameters reaching statistical significance were EndoCAb $\operatorname{IgA}(p=0.046)$ and EndoCAb $\operatorname{IgM}(p=0.022)$ in the HCV negative arm, showing higher numbers in patients on ART. No difference in any of markers tested was found in the $\mathrm{HCV}$ positive group based on ART (Table 6). The CK-18 level significantly differed study arms for both in ART receiving patients $(p<0.001)$ and in patients without ART $(p=0.019)$ (Table 7). In the HCV positive patient arm, in patients who did not receive ART, the EndoCAb IgM level was positively correlated with CD4+ $\mathrm{T}$ cell count $\left(\mathrm{r}_{\mathrm{s}}=\right.$ $0.554, p=0.032$ ) (Fig. 3), and negative moderate correlations were found with LPS $\left(\mathrm{r}_{\mathrm{s}}=-0.396, p=0.143\right)$ and HIV RNA ( $\left.r_{s}=-0.356, p=0.193\right)$, though without reaching statistical significance. In addition, in the HCV positive patient arm in patients who did not receive ART, EndoCAb IgG was correlated negatively with CD4+ $\mathrm{T}$ cell count $\left(\mathrm{r}_{\mathrm{s}}=\right.$ $-0.714, p=0.003$ ) (Fig. 4) and moderately positive correlation was found between LPS and HIV RNA $\left(\mathrm{r}_{\mathrm{s}}=0.402, p=\right.$ 0.022). In patients with ART, the EndoCAb IgM level was not significantly correlated with the CD4+ T cell count $\left(\mathrm{r}_{\mathrm{s}}=\right.$

DIFFERENCES IN MARKER LEVELS ACCORDING TO HCV PRESENCE AND HIV TREATMENT

\begin{tabular}{|c|c|c|c|}
\hline & Treatment & No treatment & $p$ value \\
\hline \multicolumn{4}{|l|}{ HCV positive patients } \\
\hline LPS, EU/ml & $9.66 \pm 3.91$ & $9.96 \pm 3.74$ & 0.742 \\
\hline EndoCAb IgA, U/ml & $55.44(24.46-133.11)$ & 30.37 (22.91-61.75) & 0.142 \\
\hline EndoCAb IgM, U/ml & $18.74(16.46-47.67)$ & $18.01(11.90-58.53)$ & 0.766 \\
\hline EndoCAb IgG, U/ml & $244.94(54.67-382.44)$ & $80.10(51.90-229.46)$ & 0.350 \\
\hline CK18, U/1 & $192.60(153.50-240.00)$ & 199.55 (164.95-398.85) & 0.146 \\
\hline Cyt-c, ng/ml & $0.25(0.24-0.31)$ & $0.25(0.24-0.36)$ & 0.612 \\
\hline \multicolumn{4}{|l|}{ HCV negative patients } \\
\hline LPS, EU/ml & $10.96 \pm 5.31$ & $9.62 \pm 4.45$ & 0.179 \\
\hline EndoCAb IgA, U/ml & $34.47(17.50-54.67)$ & $20.40(14.04-30.95)$ & 0.046 \\
\hline EndoCAb IgM, U/ml & $17.02(14.23-67.26)$ & $15.34(13.53-16.02)$ & 0.022 \\
\hline CK18, U/1 & $162.40(136.60-192.83)$ & $162.40(138.60-187.80)$ & 0.935 \\
\hline Cyt-c, ng/ml & $0.27(0.24-0.34)$ & $0.26(0.25-0.29)$ & 0.605 \\
\hline
\end{tabular}

For abbrev. see Table 2

DIFFERENCES IN MARKER LEVELS ACCORDING TO HIV TREATMENT AND HCV PRESENCE

\begin{tabular}{|c|c|c|c|}
\hline & HCV positive patients & HCV negative patients & $p$ value \\
\hline \multicolumn{4}{|c|}{ Patients on antiretroviral treatment } \\
\hline LPS, EU/ml & $9.66 \pm 3.91$ & $10.96 \pm 5.31$ & 0.625 \\
\hline EndoCAb IgA, U/ml & $55.44(24.46-133.11)$ & $34.47(17.50-54.67)$ & 0.370 \\
\hline EndoCAb IgM, U/ml & $18.74(16.46-47.67)$ & $17.02(14.23-67.26)$ & 0.427 \\
\hline EndoCAb IgG, U/ml & $244.94(54.67-382.44)$ & $95.15(78.20-233.04)$ & 0.405 \\
\hline Cyt-c, ng/ml & $0.25(0.24-0.31)$ & $0.27(0.24-0.34)$ & 0.679 \\
\hline \multicolumn{4}{|c|}{ Patients with no antiretroviral treatment } \\
\hline LPS, EU/ml & $9.96 \pm 3.74$ & $9.62 \pm 4.45$ & 0.732 \\
\hline EndoCAb IgA, U/ml & $30.37(22.91-61.75)$ & $20.40(14.04-30.95)$ & 0.113 \\
\hline EndoCAb IgM, U/ml & $18.01(11.90-58.53)$ & $15.34(13.53-16.02)$ & 0.622 \\
\hline EndoCAb IgG, U/ml & $80.10(51.90-229.46)$ & $71.45(61.07-218.15)$ & 0.800 \\
\hline Cyt-c, ng/ml & $0.25(0.24-0.36)$ & $0.26(0.25-0.29)$ & 0.630 \\
\hline
\end{tabular}

For abbrev. see Table 2. 


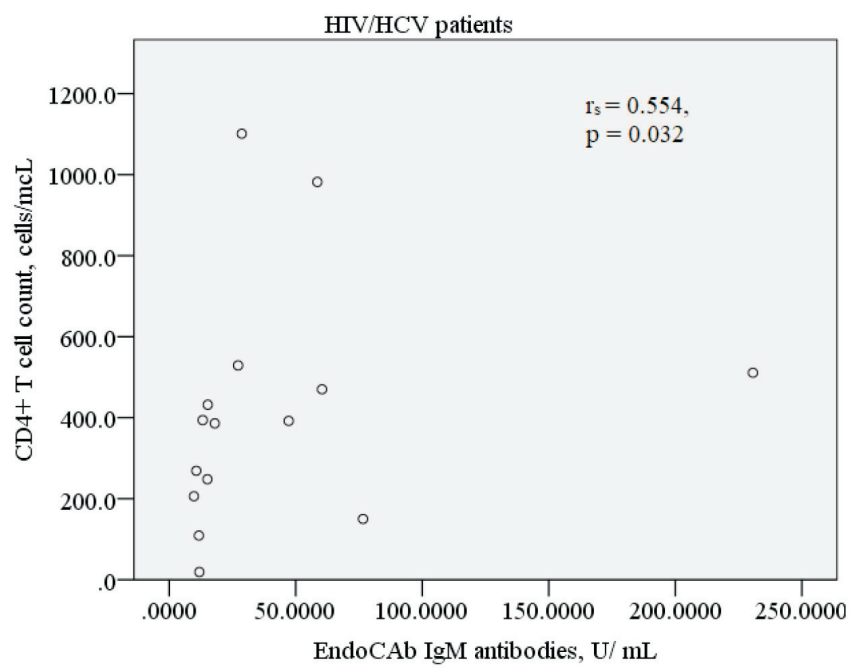

Fig. 3. Plasma EndoCAb IgM correlation with CD4+ T cells in HCV positive antiretroviral treatment (ART) negative patients

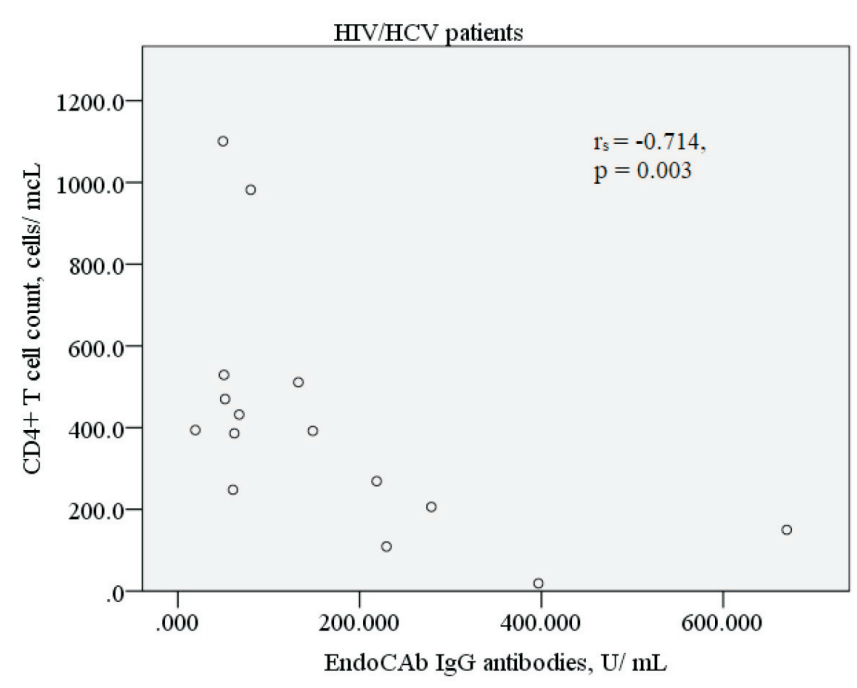

Fig. 4. Plasma EndoCAb IgG correlation with CD4+ T cells in HCV positive ART negative patients

$-0.13, p=0.61$ ), nor with LPS and HIV RNA. Statistically significant correlation was not observed for EndoCAb $\mathrm{IgG}$ and CD4+ $\mathrm{T}$ cell count $\left(\mathrm{r}_{\mathrm{s}}=-0.390, p=0.122\right)$, nor between LPS and HIV RNA. In HCV negative patients no statistically significant correlations were found for these parameters, nor in patients with ART, nor without ART.

\section{DISCUSSION}

Immune activation and consequent increase of different surrogate markers in HIV infected patient plasma compared to healthy individuals have been previously reported (Marchetti et al., 2008; 2011; Sandler and Douek, 2012). Some studies suggested higher levels of microbial translocation markers also in $\mathrm{HCV}$ patients vs healthy controls (Jirillo et al., 1998; Caradonna et al., 2002; Nien et al., 2017).

In our study we measured plasma or serum levels of LPS, EndoCAb antibodies, CK18 and Cyt-c in HIV monoin- fected and coinfected with HCV patients as well as tested for difference in markers depending on $\mathrm{CD} 4+\mathrm{T}$ cell count and ART.

We did not observe statistical difference in LPS levels between HIV monoinfected and HIV/HCV patients, which has been shown directly or indirectly in other studies (Chan et al., 1997; Albillos et al., 2003). In chronic liver disease increase of LPS increase is related to the fibrosis stage in cirrhotic patients, which in our study was one of the exclusion criteria. Therefore, we speculate that HCV alone does not cause substantial changes in intestine permeability leading to increased levels of LPS in peripheral blood. Despite not reaching statistical significance, we found higher EndoCAb antibody levels in the coinfected patient group, which may be one of the contributing factors to LPS clearance from the blood, and slightly lower LPS levels in coinfected patients. A possible problem arose from use of the Limulus amebocyte lysate based assay for LPS detection in serum or plasma (Balogopal et al., 2012) due to under detection of LPS or generally lower LPS levels.

Another factor influencing LPS and other microbial translocation markers is the HIV disease stage. In patients with more pronounced HIV disease and more expressed CD4+ T cell depletion, bacterial LPS levels in peripheral circulation might be higher, causing a corresponding response and change in microbial translocation surrogate markers. Correlation of microbial translocation markers with CD4+ T cell count and HIV RNA levels have been previously reported (Abad-Fernandez et al., 2013). However, we did not find significant correlation between LPS level and CD4+ T cell count, both, in $\mathrm{HCV}$ positive and negative patients, but in $\mathrm{HIV} / \mathrm{HCV}$ coinfected patients all EndoCAb antibodies tested were higher in patients with low CD4+ T cell count.

Also, we found positive correlation between LPS and HIV RNA level, which is in agreement with other studies showing relation of microbial translocation marker reduction and decrease in HIV viral load. However, in our study this correlation was statistically significant only in $\mathrm{HCV}$ positive ART naïve patients.

Interestingly, we did not find any significant relationship between level of microbial translocation markers and HIV disease stage in HIV monoinfected patients, but relationship of HIV disease stage and viral load relation to microbial translocation marker level was seen in the HIV/ HCV coinfected patient group. It is possible that different immune processes initiated by HIV virus might be involved in bacterial translocation and immune activation.

HIV treatment supresses immune activation and promotes release of different markers in peripheral blood, therefore leading to lower rates of LPS in patients on ART (Brenchley et al., 2006; Balagopal et al., 2008). As a result of ART, low levels of LPS are associated with higher levels of Endo$\mathrm{CAb}$ antibodies, which was seen also in our study; patients on ART had higher levels of all EndoCAb antibodies tested. Therefore, we can assume that increase in EndoCAb anti- 
bodies level in HIV patients is firstly influenced by ART, following by coinfection with HCV as previously described.

In ART naïve patients, as reported also by other authors, we found that level of LPS was associated positively with level of HIV RNA and EndoCAb IgM and negatively with CD4+ $\mathrm{T}$ cell count, but only in the HCV positive patient group. This trend was much weaker in patients on ART and was not observed in HCV negative patients.

Our study results indicate the LPS level in the bloodstream in HIV monoinfected and HIV coinfected patients is similar, but responses generated by the organism are more expressed in those who are coinfected with $\mathrm{HCV}$, and especially, without HIV treatment.

Relationship between immune stimulation and liver disease progression in HIV/HCV coinfected patients has been previously reported by other authors (Balagopal et al., 2008; French et al., 2013; Marquez et al., 2015) and is thought to be multifactorial. One of the reasons is enhanced hepatic apoptosis, which we assessed using the levels of hepatocellular apoptosis marker CK18, which is a strong trigger of hepatic fibrogenesis (Rohrbach et al., 2013) and Cyt-c. In our study the CK 18 level was significantly higher in the $\mathrm{HCV}$ coinfected patient group. This finding is in agreement with other studies (Rohrbach et al., 2013) showing the effect of HCV virus on hepatic cell apoptosis leading to consequent increase of CK18 in peripheral blood. However, we did not find any significant relationship between CK18 level and CD4+ T cell count or microbial translocation markers in both patient groups, and did not find any significant difference in Cyt-c level between patient groups. Also, we no effect of ART on levels of apoptosis markers, which is consistent with other author findings (Rohrbach et al., 2013) that showed very slow reduction in CK18 level in successfully HIV treated patients. This indicates that apoptosis estimated by CK18 level is more pronounced in $\mathrm{HIV} / \mathrm{HCV}$ coinfected patients, but our data cannot strongly support effect of microbial translocation on enhanced cell apoptosis, neither in HIV/ HCV coinfected, nor HIV monoinfected patients.

Our study had some limitations: retrospective patient selection, leading to a quite diverse patient population in terms of HIV disease and treatment length, and CD4+ T cell count. Also, data was chosen at one point with no follow up of the patients and no control group. In patients coinfected with $\mathrm{HCV}$, there was no classification of HCV stages analysed, except exclusion of reported liver cirrhosis. Also, the level of EndoCAb antibodies was tested in a limited number of patients, therefore influencing statistical data analysis.

\section{ACKNOWLEDGEMENTS}

The authors thank Valentina Sondore, MD. This study was supported by National Research Programme "Biomedicine for Public Health" (BIOMEDICINE) and by corporation "Latvijas Gāze”.

\section{REFERENCES}

Abad-Fernandez, M., Vallejo, A., Hernandez-Novoa, B., Diaz, L., Gutierrez, C., Madrid, N., Angeles Munoz, M., Moreno, S. (2013). Correlation between different methods to measure microbial translocation and its association with immune activation in long-term supressed HIV-1 infected individuals. J. Acquir. Immune Defic. Syndr., 64, 149-153.

Albillos, A., de la Hera, A., Gonzalez, M., Moya, J.-L., Calleja, J.-L., Monserrat, J., Riuz-del-Arbol, L., Alvarez-Mon, M. (2003). Increased lipopolysaccharide binding protein in cirrhotic patients with marked immune and hemodynamic derangement. Hepatology, 37 (1), 208-217.

Balagopal, A., Phil, F. H., Astemborski, J., Block, T. M., Mehta, A., Long, R., Kirk, G. D., Mehta, S. H., Cox, A. L., Thomas, D. L., Ray, S. C. (2008). Human immunodeficiency virus-related microbial translocation and progression of hepatitis C. Gastroenterology, 135 (1), 226-233.

Balagopal, A., Gama, L., Franco, V., Russell, J. N., Quinn, J., Higgins, Y., Smeaton, L. M., Clements, J. E., Thomas, D. L., Gupta, A. (2012). Detection of microbial translocation in HIV and SIV infection using the Limulus amebocyte lysate assay is masked by serum and plasma. PLOS ONE, 7 (8), $1-8$.

Brenchley, J. M., Price, D. A., Schacker, T. W., Asher, T. E., Silvestri, G., Rao, S., Kazzaz, Z., Bornstein, E., Lambotte, O., Altmann, D., Blazar, B. R., Rodriguez, B., Teixeira-Johnson, L., Landay, A., Martin, J. N., Hecht, F. M., Picker, L. J., Lederman, M. M., Deeks, S. G., Douek, D. C. (2006). Microbial translocation is a cause of systemic immune activation in chronic HIV infection. Nature Med., 12, 1365-1371.

Caradonna, L., Mastronardi, M. L., Magrone, T., Cozzolongo, R., Cuppone, R., Manghisi, O. G., Caccavo, D., Pellegrino, N. M., Amoroso, A., Jirillo, E., Amati, L. (2002). Biological and clinical significance of entotoxemia in the course of hepatitis C virus infection. Curr. Pharmaceut. Des., 8, 995-1005

Chan, C. C., Hwang, S. J., Lee, F. Y., Wang, S. S., Chang, F. Y., Li, C. P., Chu, C. J., Lu, R. H., Lee, S. D. (1997). Prognostic value of plasma endotoxin levels in patients with cirrhosis. Scand. J. Gastroenterol., 32 (9), 942-945.

Crane, M., Iser, D., Lewin, S. R. (2012). Human immunodeficiency virus infection and the liver. World J. Hepatol., 4 (3), 91-98.

Dinh, D. M., Volpe, G. E., Duffalo, C., Bhalchandra, S., Tai, A. K., Kane, A. V., Wanke, C. A., Ward, H. D. (2015). Intestinal microbiota, microbial translocation, and systemic inflammation in chronic HIV infection. J. Infect. Dis., 211, 19-27.

Epeldegui, M., Magpantay, L., Guo, Y., Halec, G., Cumberland, W. G., Yen, P. K., Macatangay, B., Margolick, J. B., Fositch, A. F., Wolinsky, S., Martinez-Maza, O., Hussain, S. K. (2018). A prospective study of serum microbial translocation biomarkers and risk of AIDS- related non- Hodgkin lymphoma. AIDS, 32 (7), 945-954.

Epple, H.-J., Schneider, T., Troeger, H., Kunkel, D., Allers, K., Moos, V., Amasheh, M., Loddenkemper, C., Fromm, M., Zeitz, M., Schulzke, J.-D. (2009). Impairment of the intestinal barrier is evident in untreated but absent in suppressively treated HIV- infected patients. Gut, 58, 220-227.

French, A., Evans, C. T., Agniel, D. M., Cohen, M. H., Peters, M., Landay, A. L., Desai, S. N. (2013). Microbial translocation and liver disease progression in women coinfected with HIV and hepatitis C virus. J. Infect. Dis., 208, 679-689.

Hansjee, N., Kaufmann, G. R., Strub, C., Weber, R., Battegay, M., Erb, P. (2004). Persistent apoptosis in HIV-1-infected individuals receiving potent antiretroviral therapy is associated with poor recovery of CD4 T lymphocytes. J. Acquir. Immune Defic. Syndr., 36, 671-677.

Hatano, H. (2013). Immune activation and HIV persistence: Considerations for novel therapeutic interventions. AIDS, 8 (3), 211-216.

Jiang, W., Lederman, M. M., Hunt, P., Sieg, S. F., Haley, K., Rodriguez, B., Landay, A., Martin, J., Sinclair, E., Asher, A. I., Deeks, S. G., Douek, D. C., Brenchley, J. M. (2009). Plasma levels of bacterial DNA correlate with immune activation and the magnitude of immune restoration in persons with antiretroviral-treated HIV infection. J. Infect. Dis., 199 (8), 1177-1185. 
Jirillo, E., Amati, L., Caradonna, L., Greco, B., Cozzolongo, R., Cuppone, R., Piazzolla, G., Caccavo, D., Antonaci, S., Manghisi, O. G. (1998). Soluble (s) CD14 and plasmatic lipopolysaccharides (LPS) in patients with chronic hepatitis $\mathrm{C}$ before and after treatment with interferon (IFN)- $\alpha$. Immunopharmacol. Immunotoxicol., 20 (1), 1-14.

Kronenberger, B., von Wagner, M., Herrmann, E., Mihm, U., Piiper, A., Sarrazin, C., Zeuzem, S. (2005). Apoptotic cytokeratin 18 neoepitopes in serum of patients with chronic hepatitis C. J. Viral Hepat., 12, 307-314.

Lopez-Cortes, L. F., Trujillo-Rodriguez, M., Baez-Palomo, A., Benmarzouk-Hidalgo, O. J., Dominguez-Molina, B., Milanes-Guisado, Y., Espinosa, N., Viciana, P., Gutierrez-Valencia, A. (2018). Eradication of hepatitis $\mathrm{C}$ virus $(\mathrm{HCV})$ reduces immune activation, microbial translocation, and the HIV DNA level in HIV/HCV-coinfected patients. J. Infect. Dis., 218 (4), 624-632.

Macias, J., Japon, M. A., Saez, C., Palacios, R. B., Mira, J. A., Garcia-Garcia, J. A., Merchante, N., Vergara, S., Lozano, F., Gomez-Mateos, J., Pineda, J. A. (2005). Increased hepatocyte Fas expression and apoptosis in HIV and hepatitis C virus infection. J. Infect. Dis., 192, 1566-1576.

Marchetti, G., Bellistri, G. M., Borghi, E., Tincati, C., Ferramosca, S., La Francesca, M., Morace, G., Gori, A., d Arminio Monforte, A. (2008). Microbial translocation is associated with sustained failure in $\mathrm{CD}+\mathrm{T}$-cell reconstitution in HIV-infected patients on long-term highly active antiretroviral therapy. AIDS, 22, 2035-2044.

Marchetti, G., Cozzi-Lepri, A., Merlini, E., Bellistri, G. M., Castagna, A., Galli, M., Verrucchi, G., Antinori, A., Costantini, A., Giacometti, A., di Caro, A., D' arminio Monforte, A. (2011). Microbial translocation predicts disease progression of HIV- infected antiretroviral- naïve patients with high CD4+ cell count. AIDS, 25, 1385-1394.

Marchetti, G., Tincati, C., Silvestri, G. (2013). Microbial translocation in the pathogenesis of HIV infection and AIDS. Clin. Microbiol. Rev., 26, 2-18.

Marquez, M., Romero-Cores, P., Montes-Oca, M., Martin-Aspas, A., Soto-Cardenas, M.-J., Guerrero, F., Fernandez-Gutierrez, C., Giron-Gonzalez, J.-A. (2015). Immune activation response in chronic HIV-infected patients: Influence of hepatitis $\mathrm{C}$ virus coinfection. PLoS $O N E, 10$ (3), 1-15.

Marks, M. A., Rabkin, C. S., Engels, E. A., Busch, E., Kopp, W., Rager, H., Goedert, J. J., Chaturvedi, A. K. (2012). Markers of microbial translocation and risk of AIDS-related lymphoma. AIDS, 27, 469-474.

Mhawej, M.-J., Brunet-Francois, C., Fonteneau, R., Ernst, D., Ferre, V., Stan, G.-B., Raffi, F., Moog, C. H. (2009). Apoptosis characterizes immu- nological failure of HIV infected patients. Control Eng. Practice, 17, 798-804.

Nien, H.-C., Hsu, S.-J., Su, T.-H., Yang, P.-J., Sheu, J.-C., Wang, J.-T., Chow, L.-P., Chen, C.-L., Kao, J.-H., Yang, W.-S. (2017). High serum lipopolysaccharide-binding protein level in chronic hepatitis $\mathrm{C}$ viral infection is reduced by anti-viral treatments. PLOS ONE, 12 (1), 1-11.

Novati, S., Sacchi, P., Cima, S., Zuccaro, V., Columpsi, P., Pagani, L., Filice, G., Bruno, R. (2015). General issues on microbial translocation in HIV-infected patients. Eur. Rev. Med. Pharmacol. Sci, 19, 866-878.

de Oliveira Pinto, L. M., Lecoeur, H., Ledru, E., Rapp, C., Patey, O., Gougeon, M.-L. (2002). Lack of control of T cell apoptosis under HAART. Influence of therapy regimen in vivo and in vitro. AIDS, 16, 329-339.

Parfieniuk-Kowerda, A., Lapinski T. W., Rogalska-Plonska, M., Swiderska, M., Panasiuk, A., Jaroszewicz, J., Flisika, R. (2013). Serum cytochrome c and m30-neoepitope of cytokeratin-18 in chronic hepatitis C. Liver Int., 34, $544-550$.

Roger, P.-M., Breittmayer, J.-P., Durant, J., Sanderson, F., Ceppi, C., Brignone, C., Cua, E., Clevenbergh, P., Fuzibet, J.-G., Pesce, A., Bernard, A., Dellamonica, P. (2002). Early CD4+ T cell recovery in human immunodeficiency virus-infected patients receiving effective therapy is related to a down-regulation of apoptosis and not to proliferation. J. Infect. Dis., 185, 463-470.

Rohrbach, J., Stickel, F., Schmid, P., Thormann, W., Kovari, H., Scherrer, A., Gunthard, H. F., Vuichard, D., Cavassini, M., Ambrosioni, J., Bernasconi, E., Furrer, H., Rauch, A. (2013). Changes in biomarkers of liver disease during successful combination antiretroviral therapy in HIV-HCV-coinfected individuals. Antiviral Ther., 19, 149-159.

Sandler, N. G., Wand, H., Roque, A., Law, M., Nason, M. C., Nixon, D. E., Pedersen, C., Ruxrungtham, K., Lewin, S. R., Emery, S., Neaton, J. D., Brenchley, J. M., Deeks, S. G., Sereti, I., Douek, D. C. (2011). Plasma levels of soluble CD14 independently predict mortality in HIV patients. J. Infect. Dis., 203, 780-790.

Sandler, N. G., Douek, D. C. (2012). Microbial translocation in HIV infection: Causes, consequences and treatment opportunities. Nature Rev. Microbiol., 10, 655-666.

Seidel, N., Volkmann, X., Langer, F., Flemming, P., Manns, M. P., Schulze-Osthoff, K., Bantel, H. (2005). The extent of liver steatosis in chronic hepatitis $\mathrm{C}$ virus infection is mirrored by caspase activity in serum. Hepatology, 42, 113-120.

Vassallo, M., Mercie, P., Cottalorda, J., Ticchioni, M., Dellamonica, P. (2012). The role of lipopolysaccharide as a marker of immune activation in HIV-1 infected patients: A systematic literature review. Virology J., 9 (174), 1-8.

Received 30 October 2018

Accepted in the final form 28 February 2019

\section{MIKROBU TRANSLOKĀCIJAS UN ŠŪNU APOPTOZES MARĶIERU ATŠĶIRĪBAS HIV MONOINFICĒTIEM UN HIV/HCV KOINFICĒTIEM PACIENTIEM}

Mikrobu translokācijai ir būtiska loma cilvēka imūndeficīta vīrusa (HIV) infekcijas izraisītas imūnās aktivācijas uzturēšanā. Tas savukārt ir viens no faktoriem, kas veicina ātrāku aknu slimības progresēšanu un paātrinātu šūnu apoptozi. Darba mērkis bija noskaidrot mikrobu translokācijas un apoptozes rādītāju iespējamās atškirīibas HIV monoinficētiem un koinficētiem ar hepatìtu C (HCV) pacientiem, un analizēt šos rādīiājus atkarībā no HIV imūnā statusa un antiretrovirāāās terapijas (ART). Pêtījumā tika iekḷauti 78 HIV inficēti un 105 HIV/HCV koinficēti pacienti, kuri ārstējās Rīgas Austrumu klīniskās universitātes slimnīcā. Tika noteikti lipopolisaharīdu (LPS), endotoksīnu serdes antivielu (EndoCAb), citokeratīna 18 (CK18) un citohroma c (Cyt-c) līmeṇi asin̄is. Statistiski ticamas atškirības netika atklātas LPS, EndoCAb, Cyt-c rādītājos starp HIV monoinficētiem un koinficētiem ar HCV pacientiem. CK18 rādītāji bija augstāki HIV/HCV grupā. Tika konstatēta korelācija starp CD4+ šūnu skaitu un EndoCAb antivielām HCV pozitīviem pacientiem. Statistiski ticams apstiprinājums ART ietekmei uz EndoCAb IgA un IgM antivielu rādītājiem tika iegūts HIV monoinficēto pacientu grupā. HIV/HCV koinficēto pacientu grupā, kuri saņēma ART, tika konstatēta korelācija starp CD4+ šūnu skaitu, EndoCAb antivielām un LPS. HIV un HCV koinfekcija var izraisīt lielāku EndoCAb antivielu produkciju un augstākus apoptozes marḳieru rādītājus, neskatoties uz līdzīgiem LPS rādītājiem. ART piemīt pozitīva ietekme imūnās aktivācijas kontrolē. 